\title{
DETETEKSI KELAINAN PADA CRANIUM DENGAN CAHAYA ALTERNATIF DALAM LINGKUP FOTOGRAFI FORENSIK
}

\author{
RIZKY SUGIANTO PUTRI \\ Program Studi S2 Ilmu Forensik, Sekolah Pascasarjana Universitas Airlangga \\ Jl. Airlangga No. 4-6 Surabaya, Jawa Timur, Telp. (031)5914042 \\ rizky.sugianto.p@gmail.com
}

\begin{abstract}
Abstrak
Latar belakang: Sinar inframerah dan ultraviolet termasuk gelombang elektromagnetik, yang dapat menampilkan objek invisible spectrum. Oleh karena itu kedua sinar tersebut sering dimanfaatkan dalam lingkup fotografi forensik, sebagai sumber cahaya alternatif (Alternate Light Source). Namun penggunaan teknik ALS masih terbatas pada beberapa objek, sebagai seorang Antropolog yang mempelajari fotografi, penulis ingin mengembangkan teknik ALS ke media lain seperti cranium manusia. Penelitian ini penting dilakukan untuk membantu proses identifikasi, dan belum pernah dilakukan di Indonesia. Metode: Penelitian dilakukan dengan memotret 11 cranium dalam lima norma. Setelah itu cranium dipaparkan dengan sinar ultraviolet, dan sinar inframerah. Proses analisis dilakukan menggunakan program Adobe Photoshop, untuk dilakukan pengamatan kelainan. Hasil: Kelainan yang dapat teramati adalah: (1) adanya porotic; (2) penipisan periosteum; (3) adanya trauma; (4) memperjelas struktur permukaan gigi; (5) memperjelas atrisi gigi; (6) memperjelas karies gigi; (7) memperjelas calculus gigi; (8) memperjelas pengamatan sutura; (9) menunjukkan perbedaan warna taponomi; (10) adanya aktifitas hewan; (11) adanya abrasi periosteum; dan (12) kontak dengan lem, kertas perekat, butiran pasir, serat benang, dan rambut. Simpulan: Diaplikasikannya teknik ALS pada 11 cranium, dapat menunjukkan beberapa kelainan seperti abnormalitas pada tulang dan gigi, perbedaan struktur dan warna permukaan cranium, modifikasi tulang, dan kontak cranium dengan benda asing.
\end{abstract}

Kata Kunci: antropologi forensik, fotografi forensik, sinar inframerah, sinar ultraviolet.

\begin{abstract}
Background: Infrared and ultraviolet rays are part of electromagnetic waves, which can help to see object in invisible spectrum. Both rays are often used in forensic photography, as an alternate light sourch (ALS). However both rays's uses are still in limited objects, as an Anthropologist who studies photography, author wants to develop ALS technique to other media like cranium. This research is important for identification and it has never been done in Indonesia. Method: Taking photo of 11 cranium in five norms, and all photo is conducted by exposing ultraviolet and infrared rays. After that photo is processed using Adobe Photoshop, to be observed and analyzed. Result: Those abnormalities are: (1) porotic; (2) thinning of periosteal; (3) trauma; (4) clarify the structure of dental surface; (5) dental attrition; (6) dental caries; (7) dental calculus; (8) further observation on sutures; (9) shows variations color on taphonomic process; (10) presence of animal activity; (11) periosteal abrasion; (12) contact with glue, adhesive paper, sand, fiber, and hair. Conclusion: The application of ALS technique that exposure 11 cranium, may shows abnormalities such as in bones and tooth, differences in structure and color on the cranium, modification of bone, and contact with foreign objects.
\end{abstract}

Keyword: forensic anthropology, forensic photography, infrared ray, ultraviolet light. 


\section{PENDAHULUAN}

Penggunaan teknik ALS dengan sinar inframerah (IR) dan ultraviolet (UV) dalam fotografi forensik, sangat untuk kepentingan identifikasi. Para praktisi forensik seperti fotografer forensik, menggunakan teknik ALS untuk melihat tanda-tanda kekerasan, seperti bekas gigitan atau bite mark, memar, bentuk tato, dan pola perlukaan. Selain itu teknik ALS biasanya juga digunakan untuk melihat bukti fisik seperti ada tidaknya cairan tubuh atau body fluids, berupa darah, sperma, air liur dan seterusnya. Pembuktian keaslian dokumen juga turut memanfaatkan teknik ALS ini, kemudian juga untuk mencari jejak residu, jejak ban, jejak sepatu, dan lain sebagainya.

Objek-objek tersebut hanya dapat dilihat menggunakan sinar IR dan UV, yang termasuk dalam bagian cahaya dari gelombang elektromagnetik, dan kedua jenis cahaya tersebut dapat menampilkan spektrum yang tidak terlihat (invicible spectrum) oleh manusia. Pengelihatan manusia hanya mampu melihat spektrum yang terlihat (visible spectrum), yang biasa dikenal dengan warna pelangi seperti violet, ungu, biru, hijau, kuning, merah, dan jingga (Marin \& Buszka, 2013). Sinar IR memiliki panjang gelombang sekitar $700 \mathrm{~nm}-1 \mathrm{~mm}$, sedangkan sinar UV memiliki panjang gelombang sekitar $10 \mathrm{~nm}-400$ $\mathrm{nm}$. Objek tersebut disebut juga dengan bukti fisik, di mana bukti tersebut bersifat sensitif terhadap cahaya IR dan UV. Oleh karena itu objek tersebut hanya dapat terlihat oleh mata manusia dengan tiga sifat yakni terabsorbsi, ter-refleksi, dan juga tertransmisi, setelah diberi paparan sinar IR dan UV (Marin \& Buszka, 2013).

Namun penggunaan sinar IR dan UV hanya terbatas dilakukan pada beberapa media, seperti kulit manusia (melihat lebam, bekas gigitan, dan lain sebagainya), kain (melihat cairan tubuh), kertas (melihat keaslian dokumen), tanah (melihat jejas kaki), dan pada media lain (melihat tinta, sidik jari, bubuk residu, dan lain sebagainya (Marin \& Buszka, 2013). Untuk itu sebagai seorang Antropolog, peneliti bertujuan untuk mengembangkan teknik ALS ini pada media tulang manusia khususnya cranium. Antropologi memiliki ilmu terapan yakni Antropologi Forensik, yang secara langsung bersinggungan dengan rangka manusia terkait dengan kepentingan hukum. Tugas seorang Antropolog Forensik adalah memberikan keterangan ahli atau memberikan bukti-bukti identifikasi pada sisa rangka manusia, seperti ras, jenis kelamin, usia, tinggi badan, usia ketika mati, dan juga individualisasi (Katzenberg \& Saunders, 2008).

Identifikasi serta deskripsi sisa rangka manusia merupakan salah satu tugas utama dari seorang Antropolog Forensik. Untuk dapat mengidentifikasi serta mendeskripsikan sisa rangka, diperlukan metode tertentu yang dapat diterapkan. Metode tersebut adalah dengan metode antroposkopi, osteometri, kimiawi, histologi, dan juga dokumentasi atau fotografi.

Oleh karena itu alasan atau latar belakang dalam penelitian ini, yakni untuk mengembangkan fotografi forensik dengan teknik ALS pada cranium. Cranium sendiri merupakan salah satu dari sisa rangka yang paling sering ditemukan. Selain itu penelitian ini juga bertujuan untuk mendeteksi adanya kelainan pada cranium, dengan menggunakan teknik ALS yang telah dimodifikasi agar dapat menggunakan kamera DSLR biasa.

\section{TINJAUAN PUSTAKA}

\subsection{Penelitian terdahulu}

Beberapa penelitian sebelumnya memanfaatkan sinar infra merah dan ultraviolet, dalam lingkup fotografi forensik. Salah satunya seperti penelitian yang dilakukan oleh Broux et al., menggunakan sinar IR untuk melihat sisa tulisan yang ada pada alas dokumen kosong (gambar 1) dan melihat bubuk residu pada sepotong kain denim (gambar 2) (Broux, McCaul, \& Shimamoto, 2007). Penelitian berikutnya dilakukan oleh Richard yang menggunakan sinar UV sebagai paparan untuk melihat adanya bekas gigitan (bite mark) pada kulit manusia (gambar 3) dan jejas sepatu olahraga yang tersisa di pasir (gambar 4) (Richards, 2010). Penelitian lainnya juga dilakukan oleh Klingle dan Reiter, yang menggunakan sinar IR untuk melihat dan mengukur lebih jelas pola perlukaan (gambar 5) dan melihat tato lebih jelas pada kulit (Klingle \& Reiter, 2008).
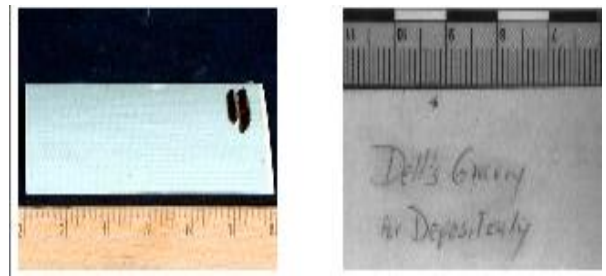

Gambar 1. Alas dokumen terlihat kosong (kiri) dan alas dokumen dengan sinar IR (kanan) 
Sumber: (Broux, McCaul, \& Shimamoto, 2007)

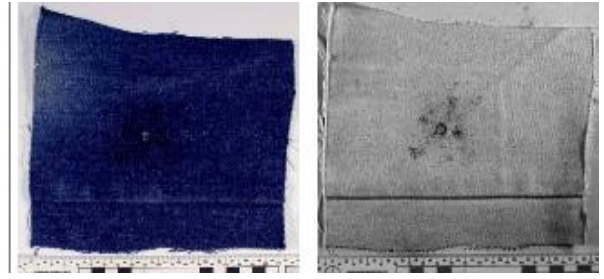

Gambar 2. Bubuk residu dapat dilihat dengan sinar IR pada celana denim (kanan)

Sumber: (Broux, McCaul, \& Shimamoto, 2007)

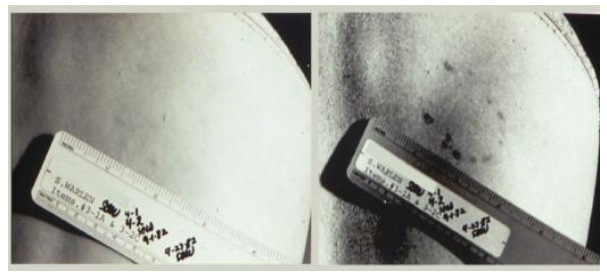

Gambar 3. Bekas gigitan yang terlihat jelas dengan sinar UV (kanan)

Sumber: (Richards, 2010)

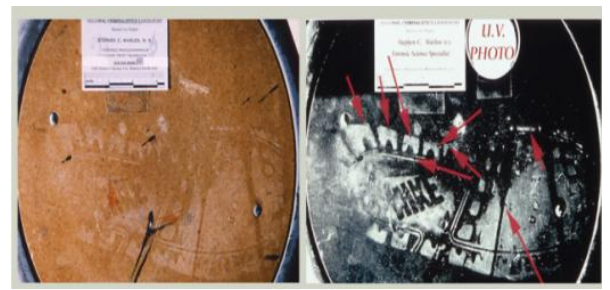

Gambar 4. Jejas sepatu yang terlihat jelas dengan sinar UV (kanan)

Sumber: (Richards, 2010)
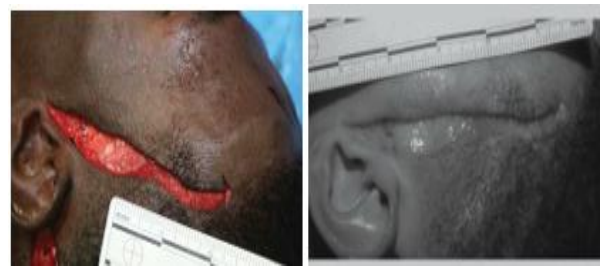

Gambar 5. Pola perlukaan dapat lebih jelas terlihat dengan sinar IR (kanan)

Sumber: (Klingle \& Reiter, 2008)
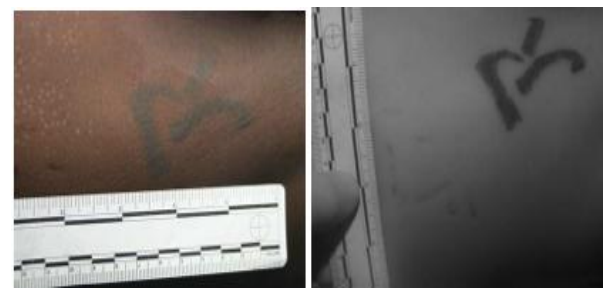

Gambar 6. Motif tato dapat lebih jelas terlihat dengan sinar IR (kanan)

Sumber: (Klingle \& Reiter, 2008)

\subsection{Antropologi forensik}

Antropologi forensik memanfaatkan pengetahuan mengenai fisik manusia untuk mengumpulkan dan menganalisis bukti, untuk kepentingan pengadilan. Jadi tujuan utama dari Antropolog Forensik adalah membantu mengidentifikasi dan mencari tahu apa yang terjadi dengan individu tersebut. Tujuan lainnya adalah untuk mencari tahu informasi biologis berdasarkan tulang-belulang yang tersisa, dengan harapan dapat memahami lebih jauh mengenai variasi manusia melalui tulang (Katzenberg \& Saunders, 2008).

Selain mempelajari mengenai tulang manusia, Antropolog Forensik juga mempelajari mengenai gigi geligi. Pengetahuan Antropolog mengenai gigi berguna untuk membantu mengidentifikasi identitas seseorang, seperti mengidentifikasi ras, mengestimasi usia, mengetahui kebiasaan yang dilakukan ketika hidup, mengetahui kebudayaan yang dianut, selain itu melalui gigi juga dapat diketahui status sosial dan ekonomi individu ketika hidup.

\subsection{Fotografi forensik}

Fotografi berasal dari bahasa Yunani, yang secara etiologi memiliki arti "phos" adalah cahaya, dan "graphos" adalah menulis, apabila diartikan menjadi menulis dengan cahaya. Menulis dengan cahaya tidak dapat dilakukan dengan pena atau pensil, oleh karena itu dibutuhkan alat khusus yang dapat merekam cahaya menjadi sebuah gambar yakni kamera (Redsicker, James, Laws Jr., \& Redsicker, 2001).

Berikut beberapa bagian kamera yang penting untuk diketahui dalam lingkup fotografi, antara lain adalah: (1) aperture, lubang pada badan kamera berfungsi sebagai jalan masuk cahaya ke dalam kamera; (2) lensa, untuk mengukur dan menangkap seberapa jauh atau dekat, seberapa tajam atau kabur, seberapa detil atau distorsi suatu objek ke dalam kamera; dan (3) shutter, mengontrol seberapa banyak cahaya yang masuk ke dalam kamera (Redsicker et al., 2001).

Sebuah foto dapat dijadikan bukti vital, yang mana melalui foto dapat menggambarkan banyak makna tanpa kata. Foto tentu tidak dapat menampilkan data yang valid seperti diagram, namun sebuah foto dapat jelas 
menggambarkan 140 luka tusukan, darah yang memenuhi ruangan, keadaan korban perkosaan, dan kasus-kasus lainnya. Oleh karena itu fotografi forensik penting untuk terus dikembangkan menjadi bukti-bukti yang valid.

\subsection{Pencritaan sumber cahaya alternatif (ALS)}

Salah satu elemen dasar fotografi adalah komposisi cahaya, selama ada cahaya masuk maka sebuah foto yang baik dapat dibuat. Namun kini cahaya normal tidak cukup untuk membuat foto yang baik, terutama untuk keperluan penyidikan forensik. Beberapa bukti fisik seperti jejak residu, cairan tubuh, sidik jari, dan bukti lainnya hanya dapat dilihat menggunakan cahaya yang memiliki panjang gelombang yang berbeda dari cahaya normal, yakni sinar inframerah dan ultraviolet (Marin \& Buszka, 2013).

Sifat dari bukti fisik tersebut terhadap sinar inframerah dan ultraviolet terdiri dari tiga sifat, yakni refleksi, transmisi, dan absorpsi. Refleksi terjadi apabila sinar mengenai objek dan langsung terpantul, menyebabkan terjadinya blur atau hasil foto mengalami gangguan cahaya. Sifat kedua yakni transmisi peristiwa di mana cahaya datang kemudian diteruskan atau dibelokkan, sama seperti peristiwa memasukkan pensil ke dalam air. Absorpsi sendiri dapat menimbulkan dua efek lain yakni fluoresensi dan fosforesensi, dengan kata lain efek berpendar terang di kegelapan. Fluoresensi hanya dapat dilihat sesaat setelah absorpsi terjadi, sedangkan fosforesensi dapat dilihat selama mungkin atau terus berpendar. Seorang fotografer forensik perlu benar-benar memahami sifat-sifat ini guna mempermudah pekerjaan yang dilakukan baik di TKP maupun laboratorium (Council, 2001).

Alterante Light Source atau sumber cahaya alternatif, merupakan salah satu teknik fotografi yang umum digunakan oleh praktisi forensik, terutama oleh fotografer forensik. Penggunaan teknik ALS dapat membantu identifikasi maupun proses olah TKP menjadi lebih spesifik. Jenis ALS yang biasa digunakan oleh para fotografer forensik adalah sinar inframerah dan sinar ultraviolet (Marin \& Buszka, 2013). Secara sederhana proses dilakukannya teknik ALS, adalah dengan memaparkan salah satu dari sinar inframerah atau sinar ultraviolet pada objek foto. Setelah itu objek foto akan bereaksi terhadap radiasi sinar inframerah atau sinar ultraviolet, sesuai dengan sifatnya yaitu absorbsi dan refleksi.
Pada akhirnya kamera DLSR dengan pengaturan yang telah ditetapkan, akan menangkap reaksi dari objek foto tersebut.

\subsubsection{Sinar inframerah}

Sinar inframerah dapat sangat berguna terutama untuk kondisi yang memerlukan perbedaan jelas antara latar belakang gelap dengan kontras benda yang ingin dipotret, dan sebaiknya teknik ini dilakukan di tempat atau studio gelap. Sifat yang dapat dimunculkan ketika objek terpapar sinar inframerah secara langsung adalah refleksi dan absorbsi.

Objek dapat terrefleksi ketika sinar inframerah datang benda nampak terang dalam hasil foto, sebaliknya apabila objek mengabsorpsi sinar inframerah maka benda nampak gelap dalam hasil foto (Redsicker et al., 2001). Panjang gelombang yang tidak tepat dipaparkan ke suatu objek, akan menyebabkan transmisi sinar iframerah tidak sempurna. Hal tersebut menyebabkan hasil foto tidak menunjukkan temuan atau kelainan apapun.

\subsubsection{Sinar ultraviolet}

Sumber sinar ultraviolet yang sering digunakan dalam lingkup fotografi forensik, terdiri dari dua jenis yakni sumber kontinyu dan baris. Sumber kontinyu memancarkan sinar dengan intensitas yang berubah-ubah, disesuaikan dengan panjang gelombang yang diinginkan. Sumber garis baris hanya memancarkan sejumlah baris dengan panjang gelombang yang terbatas. Seorang fotografer forensik biasanya menggunakan sumber ultraviolet senter LED, karena dinilai praktis apabila dibandingkan dengan sumber lainnya (Marin \& Buszka, 2013).

Mengenai sifat paparan ultraviolet terhadap suatu benda, bertolakbelakang dengan sifat inframerah. Hal ini berhubungan dengan panjang gelombang ultraviolet lebih pendek dari inframerah. Oleh karena itu, sifat pancaran ultraviolet pada suatu objek adalah di mana objek mengabsorbsi radiasi ultraviolet, maka benda tersebut akan terus berpendar. Sebaliknya apabila suatu objek merefleksi radiasi ultraviolet, maka benda tersebut akan berpendar selama beberapa detik dan 
Jurnal Biosains Pascasarjana Vol. 17 (2015) pp

(C) (2015) Program Pascasarjana Universitas Airlangga, Indonesia

kemudian berwarna lebih gelap dari area di sekitarnya.

\subsection{Taponomi}

Ilmu yang mempelajari mengenai segala sesuatu yang terjadi pada sisa tubuh manusia setelah mati, disebut dengan taponomi. Terapannya adalah Taponomi Forensik yakni ilmu yang mempelajari proses perubahan postmortem yang terjadi pada sisa tubuh manusia, termasuk proses dekomposisi atau pembusukan dengan segala interaksinya dengan tumbuhan, serangga, dan hewan lainnya, untuk tujuan penyidikan pengadilan. Proses taponomi meliputi beberapa tahapan, yakni: (1) ketika individu dinyatakan mati mengalami tahap autolysis; (2) muncul tanda-tanda kematian atau mortis triad (algor mortis, livor mortis, dan rigor mortis); (3) individu mengalami pembengkakan dan pembusukan atau putrefaction; hingga (4) pembusukan akhir hingga skeletonisasi (Pokines \& Symes, 2014).

Taponomi juga merupakan salah satu tahapan dalam protokol Antropolog Forensik untuk melakukan identifikasi. Taponomi dalam tahapannya bertujuan untuk mencari informasi yang meliputi lingkungan di sekitar TKP, kondisi sisa rangka di TKP (in situ), proses recovery dan pendataan inventaris rangka, deskripsi kondisi pembusukan atau dekomposisi, aktifitas hewan, penguburan, dan lain sebagainya.

Beberapa tanda postmortem atau proses pembusukan yang sering ditemui di tulang, adalah seperti (Pokines \& Symes, 2014): (1) adanya tanda adiposa; (2) adanya retakan, baik pada tulang maupun gigi; (3) penyebab retakan, dapat disebabkan oleh udara, panas, air, mineral, mekanik, hewan, tumbuhan, maupun bakteri; (4) adanya perubahan warna, dapat disebabkan oleh mineral, adiposa, kelembapan suhu, bakteri, tumbuhan, lem, perekat dan bahan-bahan nonbiologis lainnya; (5) adanya tambahan sedimen, baik disebabkan oleh pasir, clay, lumpur, dan endapan lainnya; dan juga (6) adanya modifikasi tulang, berhubungan dengan kebudayaan, kesengajaan, bekas operasi, dan lain sebagainya. Seorang Antropolog juga harus mengetahui perubahan-perubahan postmortem tersebut, terutama seperti retakan, perubahan warna, dan juga modifikasi tulang.

\section{METODE PENELITIAN}

Bahan yang digunakan adalah: (1) 11 cranium manusia; (2) DSLR Nikon D3100; (3) filter ultraviolet (4) tripod Excell Platinum; (5) mini studio dengan latar belakang hitam; (6) lampu neon ultraviolet; (7) lampu LED inframerah; (8) lampu flash built-in (9) skala pengukuran; dan (10) clay hitam.

Metode penelitian yang dilakukan terbagi menjadi beberapa tahapan. Pertama pengamatan makroskopis dilakukan pada 20 cranium, kemudian berdasarkan beberapa kriteria seperti:

1. Cranium manusia tanpa memperhatikan keutuhan atau kelengkapan, baik tanpa mandibula, tanpa calvaria, tanpa kalota, dan juga tanpa area fasial.

2. Cranium manusia tanpa memperhatikan jenis kelamin, baik laki-laki maupun perempuan.

3. Cranium manusia tanpa memperhatikan ras atau etnis tertentu.

4. Cranium manusia tanpa memperhatikan usia, baik usia kategori I dewasa awal (2035 tahun), kategori II dewasa (35-50 tahun), dan kategori III dewasa akhir (50+ tahun) (White et al., 2012).

5. Cranium manusia dengan memperhatikan berbagai jenis perlukaan atau trauma, adanya kelainan tulang yang bersifat patologis, adanya kelainan pada gigi yang bersifat patologis, dan adanya karakteristik unik apapun seperti wormian bone pada periosteum, dan lain sebagainya.

Berdasarkan kelima karakteristik tersebut, sebanyak 11 dari 20 cranium terpilih menjadi objek penelitian. Hal tersebut dilakukan dengan tujuan mencari ada tidaknya kelainan pada objek penelitian, baik yang bersifat patologis maupun abnormalitas lainnya.

Selanjutnya proses dokumentasi dilakukan dengan cara mengambil gambar dari 11 cranium menggunakan teknik ALS, dengan memanfaatkan sinar inframerah dan ultraviolet. Pengambilan gambar dilakukan dengan meletakkan cranium pada mini studio, selain itu diletakkan juga skala ukur dan clay yang digunakan untuk menyangga posisi cranium agar sesuai dengan dataran frankfurt. Tujuan ditempatkannya cranium di dalam mini studio berlayar hitam, adalah karena dibutuhkannya keadaan yang gelap atau sedikit cahaya (underexposure). Hal ini berguna, ketika digunakannya sinar UV dan IR temuan akan dapat memantulkan cahaya kembali pada lensa kamera (Giancoli, 2005). Pengambilan gambar cranium dilakukan dengan lima norma yang berbeda, yakni norma frontalis, lateralis (kanan dan kiri), occipitalis, basilaris, dan vertikalis. Secara bergantian pengambilan gambar dilakukan, dengan memaparkan sinar inframerah, ultraviolet, dan juga cahaya normal. 
Pengaturan (setting) kamera DSLR yang digunakan dalam masing-masing foto, adalah: (1) flash, shutter speed 10s, f/4.5, dan ISO 100; (2) neon UV, shutter speed 8s, $f / 6.3$, tambahan filter jingga dan ISO 100-200; (3) LED IR, shutter speed 1/60s, f/10, flash built-in, dan ISO 100-200; (4) normal, shutter speed $10 \mathrm{~s}, \mathrm{f} / 4.5$, dan ISO 200 (Klingle \& Reiter, 2008). Jarak foto dapat disesuaikan dengan kebutuhan masing-masing norma (kondisional). Untuk hasil terbaik, peneliti menggunakan format gambar RAW atau NEF (untuk produk kamera Nikon) (Oxlee, 2000).

Proses berikutnya pengorganisasian data penelitian, yang berupa foto cranium diamati dan dikaji lebih dalam. Data foto tersebut kemudian dipilih mana foto yang sesuai untuk dijadikan sebagai hasil penelitian, dan mana yang tidak. Pemilihan didasarkan pada foto mana yang paling bermakna menampilkan berbagai temuan yang muncul di dalamnya. Karena itulah proses pengambilan gambar dilakukan sebanyak dua kali dalam selang waku yang berbeda.

Proses penyuntingan (editing) adalah tahapan berikutnya, dilakukan menggunakan Adobe Photoshop CC 2015 atau Adobe Photoshop 2008 ke atas. Proses penyuntingan dilakukan dengan menambahkan secara manual efek IR: (1) gambar terlebih dahulu dirubah ke dalam mode overlay dengan opacity sebesar 50\%; (2) memberikan tampilan monochrome (RGB 100/200/-200) pada menu new adjustment layer, efek channel mixer dan mengubah opacity menjadi $80 \%$; (3) menambahkan efek hue/saturation dengan kuning sebagai warna utama pada menu new adjustment layer; (4) geser hue pada angka -60 dan saturation pada angka 40-60 (Admin, 2013).

\section{HASIL DAN DISKUSI}

Penggunaan teknik ALS dengan pemaparan sinar inframerah dan ultraviolet pada cranium manusia, untuk mendeteksi adanya tanda-tanda kelainan cranium dapat dilakukan dengan baik. Berdasarkan analisis diketahui bahwa sinar inframerah, lebih condong untuk mendeteksi perbedaan warna pada periosteum. Hal tersebut dikarenakan panjang gelombang radiasi inframerah lebih panjang dari sinar ultraviolet. Panjang gelombang tersebut membuat perbedaan warna pada periosteum lebih menonjol dan lebih kontras. Prinsip penggunaan sinar inframerah, yang digunakan ketika ingin menonjolkan degradasi warna yang kontras.

Selain itu untuk sinar ultraviolet, lebih condong untuk mendeteksi struktur permukaan, relief permukaan, perbedaan kontur permukaan tiga dimensi (3D). Namun sinar ultraviolet tidak dapat digunakan untuk mendeteksi perbedaan warna yang signifikan, pada permukaan periosteum. Hal ini dikarenakan panjang gelombang yang lebih pendek dari sinar inframerah, menyebabkan sinar ultraviolet ini lebih baik untuk mendeteksi perbedaan kontur dan struktur permukaan cranium.

Tanda-tanda kelainan yang dapat terdeteksi tersebut antara lain adalah: (1) memperjelas adanya porotic (gambar 7. dan gambar 8.); (2) menunjukkan penipisan periosteum (gambar 9.); (3) memperjelas adanya trauma (gambar 10.); (4) memperjelas atrisi gigi (gambar 11.); (5) memperjelas karies gigi (gambar 12.); (6) memperjelas calculus gigi (gambar 13.); (7) memperjelas pengamatan sutura (gambar 14.); (8) menunjukkan perbedaan warna karena taponomi (gambar 15.); (9) menunjukkan adanya aktifitas hewan (gambar 16.); (10) menunjukkan adanya abrasi periosteum (gambar 17.); dan (11) menunjukkan kontak dengan kertas perekat, butiran pasir, dan serat benang (gambar 18. - gambar 22.).

\subsection{Temuan porotic}

Pada gambar 7., ditemukan adanya porotic pada cranium. Kelainan yang terlihat merupakan jenis porotic atau lubang-lubang kecil (porous) yang muncul di permukaan cranium. Porotic termasuk dalam tipe kelainan bentuk formasi tulang, dapat disebabkan oleh gangguan metabolisme, infeksi, trauma, tumor, anemia, kekurangan vitamin, dan lain sebagainya (Ortner, 2003).

Umumnya porotic yang timbul karena anemia terlihat di bagian dinding orbita (criba orbitalia), namun juga kerap terlihat di bagian os. Occipital dan os. Parietal (porotic hyperostosis) (Chhem \& Brothwell, 2008). Selain itu timbulnya porotic juga dapat disebabkan oleh patologi lainnya seperti scurvy, yang menunjukkan tanda porotic yang sama di area os. Occipital dan os. Parietal (Walker, et al., 2009).

Ukuran dari porotic sendiri bervariasi, di mana porotic sendiri merupakan pola lubang dengan ukuran yang terkecil. Pola yang paling besar yakni pola trabecular, yang menunjukkan pola lubang dengan ukuran besar yang dapat merubah kontur permukaan cranium.

Temuan porotic cukup terlihat dengan pengamatan makroskopis, namun dengan penambahan sinar ultraviolet pada permukaan cranium membuat porotic terlihat lebih jelas. 
Sinar ultraviolet yang dipaparkan pada cranium, diabsorbsi oleh porotic kemudian area porotic menjadi lebih gelap dari area di sekitarnya. Pada pengamatan makroskopis menggunakan cahaya normal, porotic tetap terlihat namun sukar untuk diamati tanpa melakukan perabaan.

Pada gambar 8., selain menggunakan ultraviolet cranium diberi paparan sinar inframerah dan dapat diamati, bahwa porotic dapat terlihat lebih jelas. Sinar inframerah yang ditangkap oleh porotic, dapat membuat perbedaan yang jelas antara permukaan cranium yang datar dengan permukaan yang berlubang-lubang (porotic). Hal tersebut sesuai dengan prinsip penggunaan sinar inframerah, yang digunakan ketika ingin menonjolkan degradasi warna yang kontras (Broux et al., 2007).
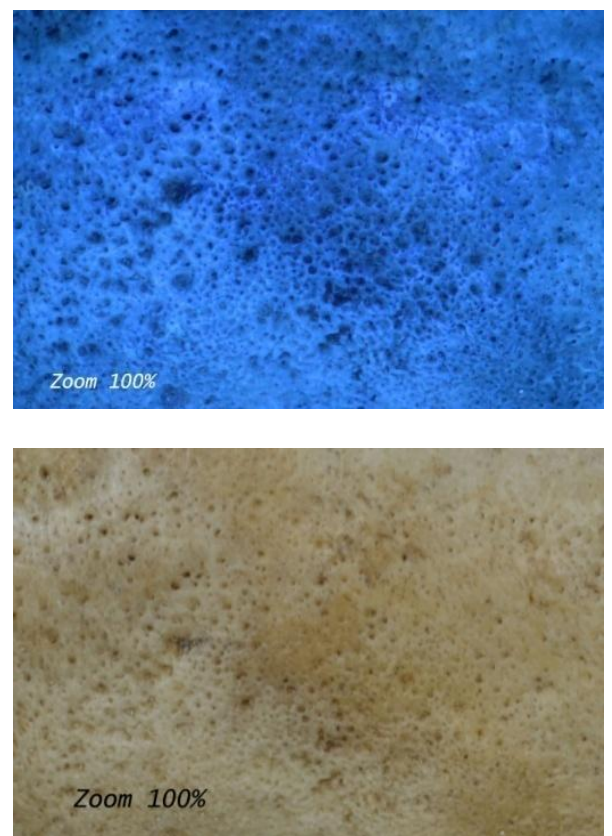

Gambar 7. Temuan porotic terlihat lebih jelas dengan foto sinar UV (atas) dibandingkan dengan foto cahaya normal (bawah) Sumber: Dokumen pribadi
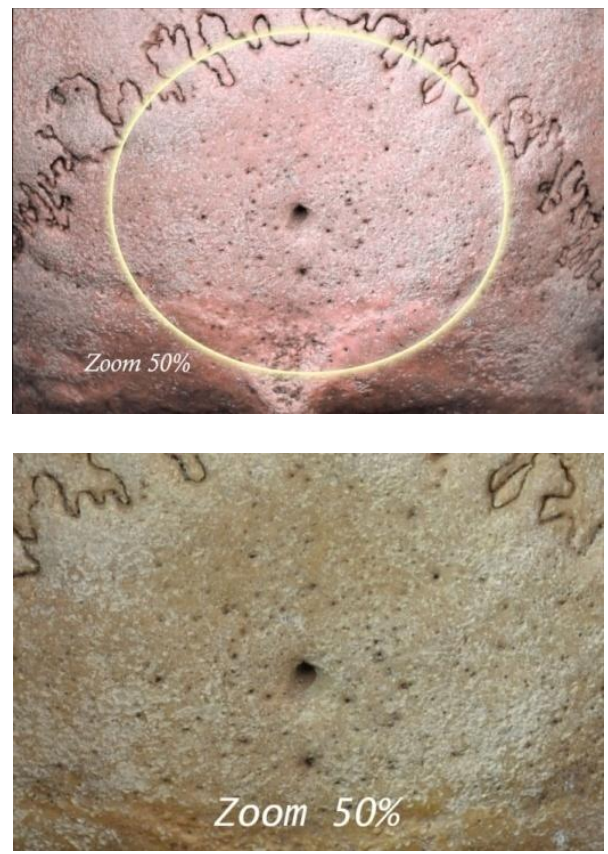

Gambar 8. Temuan porotic terlihat lebih jelas dengan foto sinar IR (atas) dibandingkan dengan foto cahaya normal (bawah) Sumber: Dokumen Pribadi

\subsection{Temuan penipisan tulang}

Pada gambar 9., ditemukan adanya penipisan tulang temporal. Kelainan yang terlihat merupakan gangguan kepadatan tulang, yang menyebabkan permukaan periosteum menjadi berkurang ketebalannya (Ortner, 2003). Area yang mengalami gangguan kepadatan adalah area os. Temporal kiri, di mana diploe menjadi sedikit terlihat dan menunjukkan adanya noda berwarna kehitaman dengan pengamatan makroskopis.

Penggunaan sinar inframerah mempermudah pengamatan adanya noda berwarna hitam yang nampak, apabila dibandingkan dengan cahaya normal. Berdasarkan tanda patologis tersebut, dugaan yang muncul adalah pernah terjadi perdarahan ekstradural dari pecahnya arteri meningeal tengah. Hal tersebut sering terjadi pada area temporal khususnya daerah squamous sutura, dan biasanya tidak dijumpai adanya fraktur di daerah tersebut. Hematoma ekstradural (EDH) jarang sekali terjadi, dan biasanya membutuhkan waktu yang lama sebelum penderita menyadari hingga meninggal dunia. Hal ini dikarenakan EDH merupakan efek post-truma, yang terkadang secara spontan dapat terjadi. EDH hanya dapat diketahui 
secara akurat menggunakan CT-scan atau Xray.

Penggunaan sinar inframerah tidak dapat memastikan bahwa EDH pernah terjadi pada cranium B, karena panjang gelombang inframerah yang terbatas dan tidak dapat menembus bagian tulang compact. Oleh karena itu munculnya tanda kelainan menyerupai EDH, hanya sebatas dugaan saja.
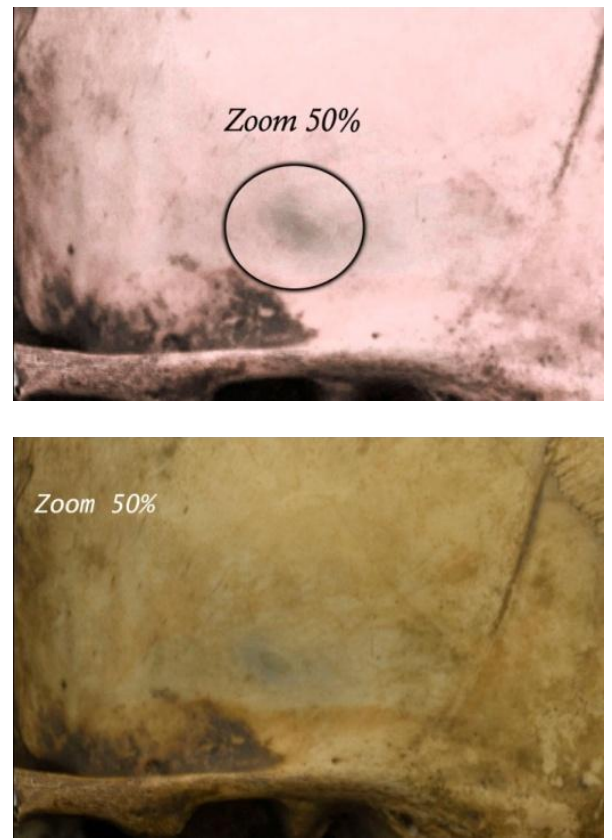

Gambar 9. Temuan penipisan periosteum terlihat lebih jelas dengan foto sinar IR (atas) dibandingkan dengan foto cahaya normal (bawah) Sumber: Dokumen pribadi

\subsection{Temuan trauma}

Pada gambar 10., ditemukan adanya trauma pada tulang parietal. Kelainan yang ditemukan diduga merupakan trauma, dengan dugaan jenis trauma stress atau adanya penekanan (Chhem \& Brothwell, 2008). Trauma sendiri menurut waktu terjadinya terbagi menjadi tiga, yakni trauma antemortem, trauma perimortem, dan trauma postmortem. Untuk menentukan jenis dan waktu terjadinya trauma dengan tepat tentu bukan perkara mudah, karena harus dapat memahami morfologi dari trauma itu sendiri, seperti sudut, struktur permukaan, dan juga bentuk (Pokines \& Symes, 2014).

Temuan yang diduga trauma ini memberikan penekanan pada bagian periosteum hingga kortikal, namun tidak sampai bagian trabekular terlihat. Penggunaan sinar ultraviolet sangat membantu pengamatan makroskopis melalui foto, di mana sinar ultraviolet diabsorbsi oleh trauma tersebut dan membuat bagian trauma berwarna lebih gelap dari bagian di sekitarnya. Penggunaan cahaya normal tidak dapat memperlihatkan trauma secara jelas, karena tidak ada perbedaan antara permukaan cranium yang mengalami trauma dan yang tidak.

Pencatatan jenis trauma dengan fotografi, merupakan salah satu metode terbaik yang patut diaplikasikan. Terutama dengan penggunaan teknik paparan sinar alternatif, membuat fotografi konvensional menjadi fotografi modifikasi yang modern. Fotografi konvensional hanya mampu menghadirkan foto trauma dengan tampilan dua dimensi, sedangkan dengan aplikasi sinar alternatif seperti sinar ultraviolet membuat foto trauma menjadi seperti tiga dimensi. Hal ini dikarenakan tampilan depth of field yang dihadirkan nampak lebih nyata, dibandingkan dengan menggunakan cahaya normal. Morfologi trauma seperti sudut dan bentuk terlihat lebih nyata, dengan diaplikasikannya sinar ultraviolet.
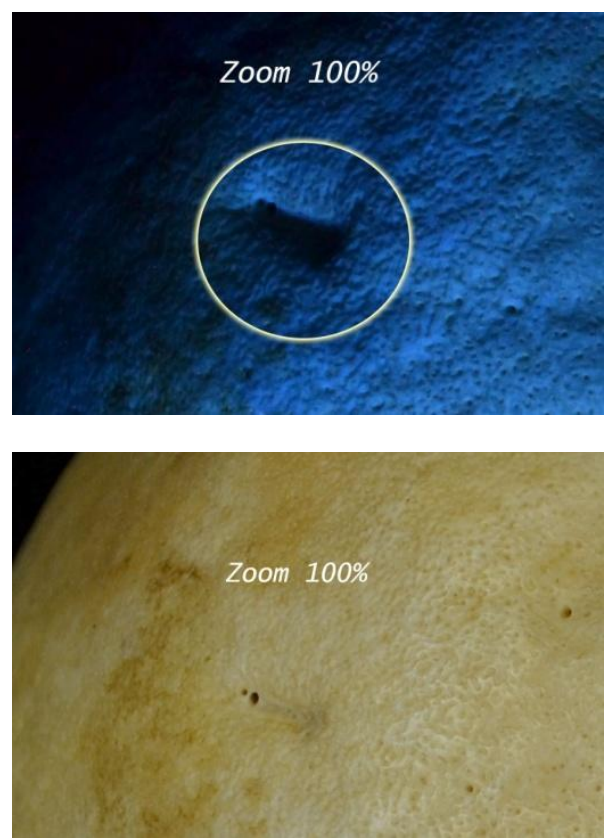

Gambar 10. Temuan trauma terlihat lebih jelas dengan foto sinar UV (atas) dibandingkan dengan foto cahaya normal (bawah) Sumber: Dokumen pribadi

\subsection{Temuan atrisi}

Pada gambar 11., ditemukan tanda-tanda atrisi gigi pada cranium. Terjadinya atrisi dapat disebabkan oleh beberapa hal, salah satu 
yang paling berpengaruh adalah jenis makanan yang dikonsumsi. Untuk mengetahui tingkat keparahan atrisi pada gigi, terdapat sistem scoring pada masing-masing gigi insisivus, kaninus, premolar, dan molar. Derajat atrisi yang paling rendah adalah muncul facets kecil, kemudian enamel mulai terlihat, dentin mulai terlihat, hingga mencapai akar gigi.

Atrisi dapat terjadi pada gigi manapun yang sering digunakan selama proses kunyah, umumnya gigi yang memiliki derajat atrisi tertinggi adalah M1 dan M2. Derajat atrisi yang paling tinggi adalah ketika seluruh mahkota gigi atau lapisan enamel telah rusak, namun hal tersebut umumnya ditemukan di gigi I, PM, dan $\mathrm{C}$ saja. Pada gigi $\mathrm{M}$ derajat atrisi yang paling tinggi adalah kehilangan salah satu cusp atau seluruh cusp hingga membentuk cekungan yang dapat membuat pulpa terbuka (exposure).

Area gigi diberi paparan sinar ultraviolet, kemudian area yang mengalami atrisi mengabsorbsi radiasi dari ultraviolet hingga area tersebut menjadi lebih gelap dari area lainnya. Pada gigi cranium atrisi terlihat dari norma basilaris, pada ULM1 serta URM1 sisi occlusal. Penggunaan sinar ultraviolet membuat permukaan M1 yang mengalami atrisi terlihat lebih jelas, apabila dibandingkan dengan penggunaan cahaya normal. Area yg diberi tanda panah merupakan atrisi yang membuat dentin terbuka (exposure). Dentin yang terpapar radiasi ultraviolet mengabsorbsi seluruh sinar, dan membuat pendaran dentin berwarna lebih gelap dari enamel atau area lainnya.

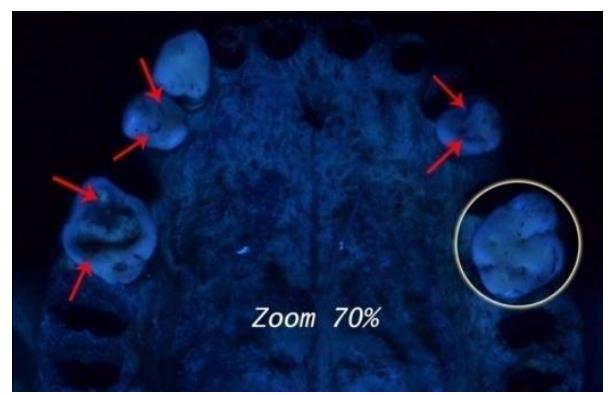

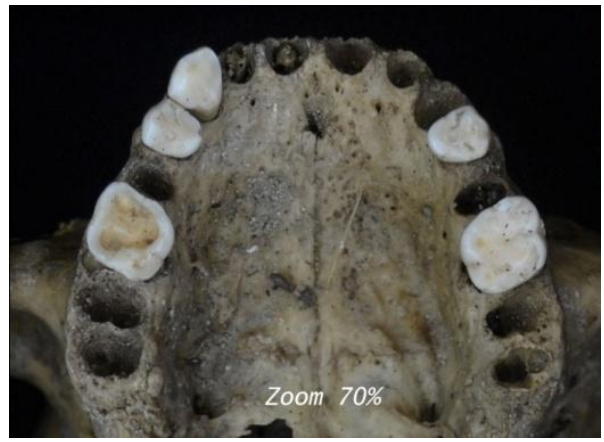

Gambar 11. Temuan atrisi gigi terlihat lebih jelas dengan foto sinar UV (atas) dibandingkan dengan foto cahaya normal (bawah) Sumber: Dokumen pribadi

\subsection{Temuan karies}

Pada gambar 12., ditemukan tanda-tanda karies gigi pada cranium. Terjadinya karies besar dipengaruhi oleh pola makan yang mengandung banyak kandungan gula dan karbohidrat. Berdasarkan lokasinya karies terjadi pada beberapa sisi, yaitu sisi occlusal, sisi inter-proksimal (sisi mesial dan distal), sisi smooth (buccal dan lingual), sisi cervical, sisi akar, hingga sisi pulpa. karies yang telah menembus dentin terlihat berwarna hitam dan dapat teramati lebih jelas, apabila dibandingkan dengan pengamatan menggunakan cahaya normal.

Karies termasuk salah satu kelainan pada gigi yang bersifat kompleks. Umumnya selain disebabkan oleh pola makan yang banyak mengkonsumsi gula dan karbohidrat, karies juga disebabkan oleh minimnya kandungan asam peptida pada liur. Asam peptida berfungsi sebagai pelindung struktur gigi, yang bertugas untuk memperlambat proses demineralisasi pada gigi.

Sesuai dengan prinsip dasar sinar inframerah yang digunakan untuk mencari kontras warna terbaik, dapat diaplikasikan pada permukaan occlusal gigi yang mengalami karies. Perbedaan warna antara permukaan gigi yang mengalami atrisi berwarna kuning, dan yang mengalami karies berwarna hitam, dapat diamati lebih jelas menggunakan sinar inframerah. 

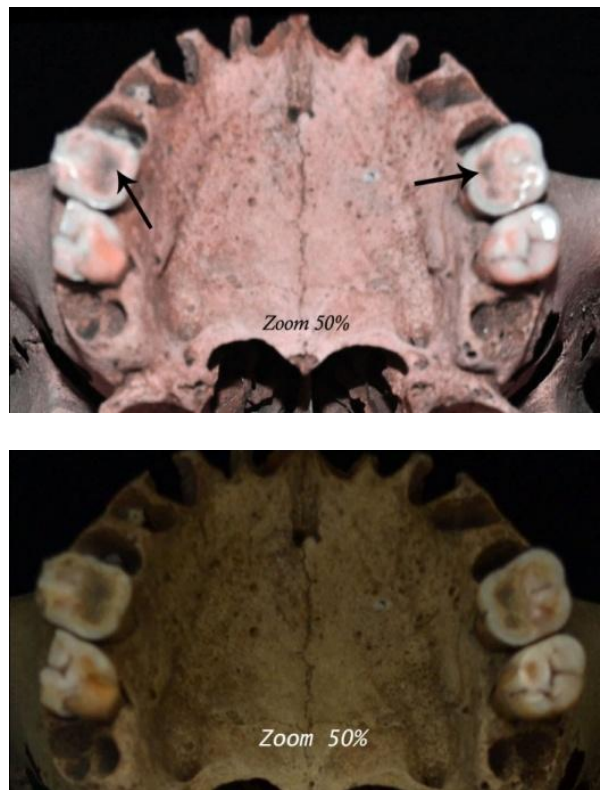

Gambar 12. Temuan karies gigi terlihat lebih jelas dengan foto sinar IR (atas) dibandingkan dengan

foto cahaya normal (bawah)

Sumber: Dokumen pribadi

\subsection{Temuan calculus}

Pada gambar 13., ditemukan tanda-tanda calculus gigi pada cranium. Terjadinya calculus disebabkan oleh menempelnya sisasisa makanan pada permukaan gigi. Munculnya calculus berkaitan erat dengan kebersihan mulut dan gigi. Calculus dapat dihilangkan dengan cara yang sederhana misalnya dengan tusuk gigi atau dengan dental floss. Namun apabila derajat calculus semakin parah maka harus diberikan perawatan khusus.

Cranium diberi paparan sinar ultraviolet, dan calculus yang menempel mengabsorbsi radiasi ultraviolet hingga berwarna lebih gelap apabila dibandingkan dengan enamel. Secara makroskopis terlihat dengan jelas bahwa calculus berwarna hitam dengan bantuan sinar ultraviolet, namun dengan cahaya normal calculus terlihat kurang jelas. Seiring dengan perkembangan teknologi, saat ini penggunaan sinar ultraviolet untuk mendeteksi calculus terus dikembangkan. Hal tersebut dilakukan karena aplikasi sinar ultraviolet dinilai lebih praktis, efisien, serta cukup akurat.
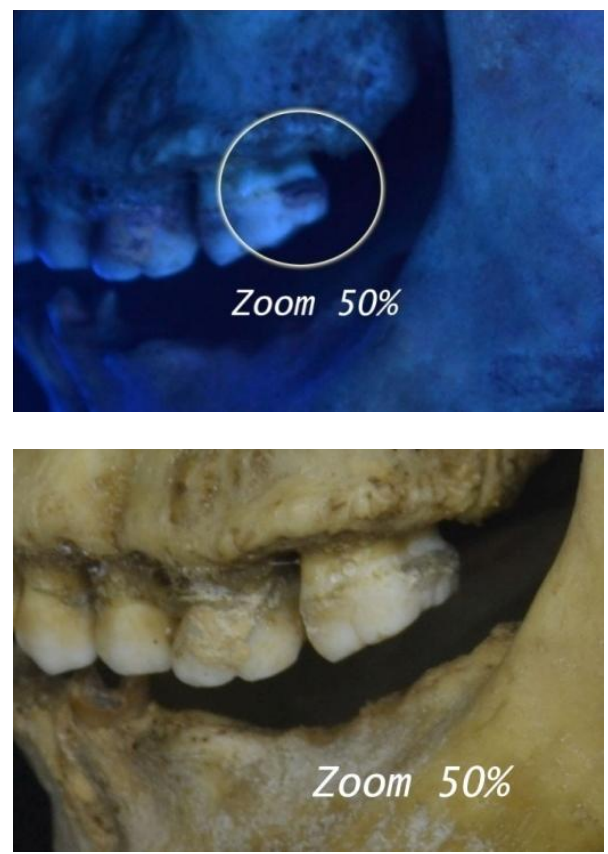

Gambar 13. Temuan calculus terlihat lebih jelas dengan foto sinar UV (atas) dibandingkan dengan foto cahaya normal (bawah) Sumber: Dokumen pribadi

\subsection{Pengamatan sutura}

Pada gambar 14., pengamatan pada sutura lebih jelas. Struktur tulang terdiri dari bahan organik dan anorganik, bahan organik adalah protein (kolagen) dan bahan anorganik adalah mineral (hydroxyapatite) (White \& Folkens, 2005). Protein (kolagen) membuat tulang menjadi fleksibel karena terdiri dari serat-serat yang elastis, sedangkan mineral (hydroxyapatite) membuat tulang menjadi kuat karena terdiri dari kalsium fosfat (Christensen et al., 2014).

Morfologi tulang manusia tentu berbeda dengan hewan, perbedaannya antara lain adalah seperti struktur permukaan, arsitek atau bentuk, ukuran dan osifikasi. Perbedaan tersebut sangat penting mengingat untuk mengetahui perbedaan antara tulang manusia dan non-manusia, merupakan salah satu protokol Antropolog Forensik dalam melakukan identifikasi. Untuk kepentingan antropologi forensik pengamatan terhadap sutura sangat penting, terutama untuk mengidentifikasi usia berdasarkan obliterasi sutura (Christensen et al., 2014).

Pengaruh taponomi dapat mengakibatkan perubahan warna pada permukaan cranium, hal tersebut dapat membuat pengamatan obliterasi sutura menjadi lebih sulit. Oleh 
karena itu teknik pemaparan sinar inframerah dapat membantu pengamatan makroskopis pada sutura cranium $\mathrm{C}$, terlihat lebih jelas dibandingkan dengan menggunakan cahaya normal.
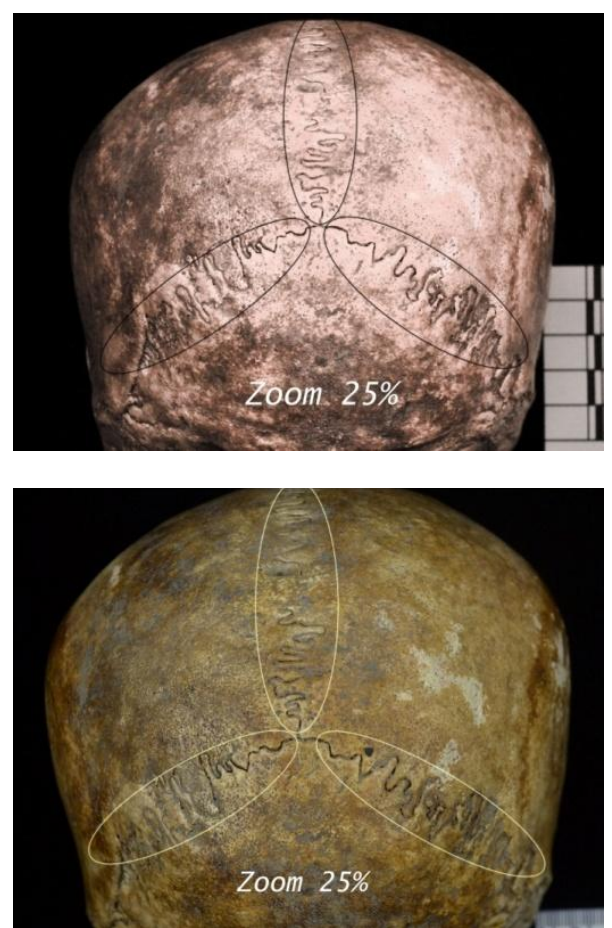

Gambar 14. Pengamatan pada sutura terlihat lebih jelas dengan foto sinar IR (atas) dibandingkan dengan foto cahaya normal (bawah)

Sumber: Dokumen pribadi

\subsection{Temuan perbedaan warna}

Pada gambar 15., perbedaan warna akibat taponomi terlihat lebih jelas. Untuk menentukan perubahan warna karena proses taponomi tidak mudah. Studi taponomi yang berkaitan dengan perubahan warna pada tulang masih tergolong sedikit dilakukan, beberapa penelitian yang pernah dilakukan juga tergantung pada kondisi lingkungan serta kandungan mineral yang ada di lingkungan tersebut. Oleh karena itu studi ini sukar untuk digeneralisasi, mengingat tingginya variasi jenis lingkungan serta kandungan mineral yang ada di seluruh dunia.

Secara umum berdasarkan penelitian yang telah dilakukan, disepakati beberapa jenis perubahan warna, seperti: (1) berwarna putih (bleaching), karena pengaruh paparan sinar matahari; (2) berwarna coklat mengkilat atau berkilau, karena dikuburkan di tanah yang dangkal; (3) berwarna coklat muda hingga coklat tua, karena dikuburkan di tanah yang mengandung bermacam-macam mineral; (4) berwarna hijau, karena terletak di lingkungan yang mengandung tembagaa atau alga hijau; dan lain sebagainya (Huculak \& Rogers, 2009).

Sinar inframerah dipaparkan ke seluruh permukaan cranium, dan area yang berwarna jingga kemerahan memantulkan kembali sinar tersebut sehingga tertangkap oleh lensa kamera. Warna jingga kemerahan dapat disebabkan oleh kontak dengan api, atau adanya perubahan suhu yang mendadak terjadi pada area tersebut. Hasil dari pengamatan makroskopis yang dilakukan dengan sinar inframerah, membuat perbedaan warna terlihat jelas, apabila dibandingkan dengan pengamatan menggunakan cahaya normal.
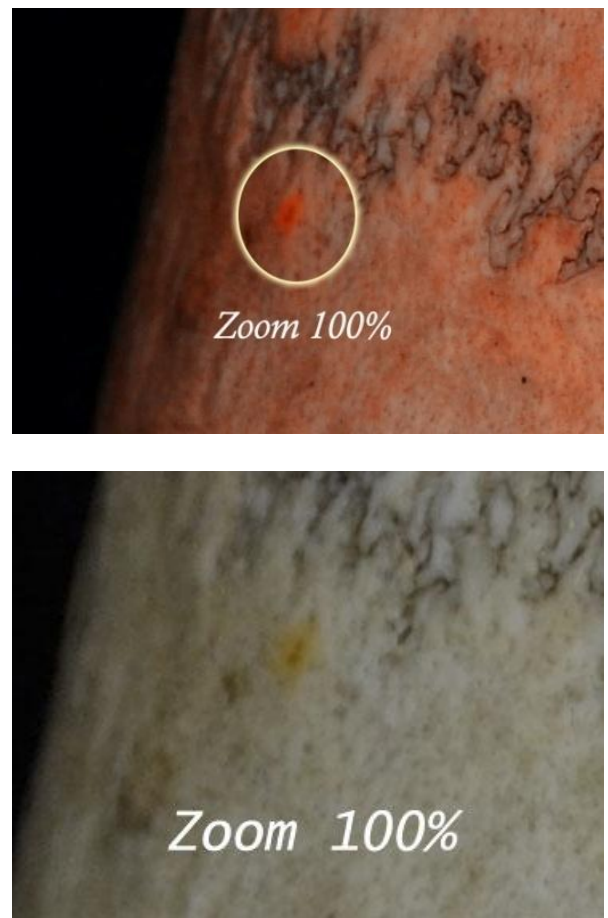

Gambar 15. Temuan perbedaan warna akibat taponomi terlihat lebih jelas dengan foto sinar IR (atas) dibandingkan dengan foto cahaya normal (bawah)

Sumber: Dokumen pribadi

\subsection{Temuan aktifitas hewan}

Pada gambar 16., adanya tanda-tanda aktifitas hewan pada tulang frontal. Aktifitas hewan yang sering dijumpai adalah seperti mencari makan (scavenging), dan juga mengasah atau mempertajam gigi yang dimiliki (gnawing). Aktifitas tersebut sering kali merusak dan meninggalkan bekas gigitan 
di tulang manusia. Hewan yang mendatangi sisa rangka umumnya adalah seperti serigala, babi, anjing, beruang, burung pemangsa daging, tikus, tupai, dan lain sebagianya (Pokines \& Symes, 2014).

Cranium diberi paparan sinar ultraviolet, dan bekas gigitan menangkap serta merefleksi radiasi ultraviolet yang datang. Hal tersebut menyebabkan bekas gigitan hewan tersebut terus berpendar selama pengamatan berlangsung. Bekas gigitan diduga dilakukan oleh kelompok hewan pengerat kecil (rodent), seperti tikus yang bertujuan untuk meruncingkan kedua gigi insisivusnya. Temuan bekas gigitan dapat diamati dengan jelas menggunakan sinar ultraviolet, apabila menggunakan cahaya normal bekas gigitan sama sekali tidak terlihat. Hal ini tentunya amat membantu seorang Antropolog Forensik untuk mempertajam analisisnya, dan juga mendeskripsikan adanya kelainan pada tulang dengan lebih detil. Terutama dengan foto sinar ultraviolet, yang dapat dijadikan sebagai alat bukti yang sah.
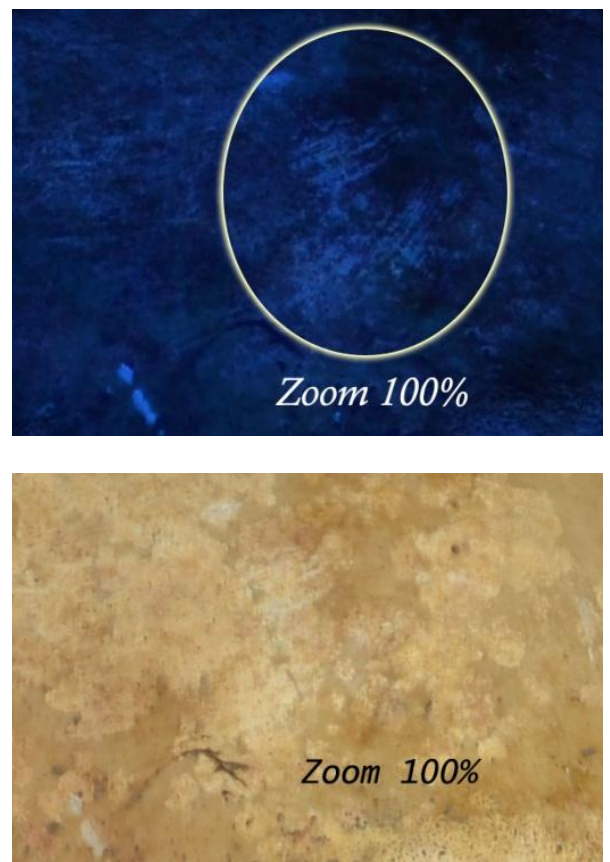

Gambar 16. Temuan abrasi akibat aktifitas hewan terlihat lebih jelas dengan foto sinar UV (atas) dibandingkan dengan foto cahaya normal (bawah) Sumber: Dokumen pribadi

\subsection{Temuan aktifitas hewan}

Pada gambar 17., adanya tanda-tanda abrasi pada tulang. Goresan pada permukaan periosteum tersebut terlihat di area tulang frontal dan tulang parietal. Kerusakan periosteum pada tulang frontal, ditemukan di sekitar area glabela, sedangkan pada tulang parietal ditemukan di dekat sutura squamous. Umumnya kerusakan periosteum terjadi pada dry bone, dapat diakibatkan oleh beberapa hal, seperti proses perawatan yang buruk, kelalaian dalam proses rekonstruksi, adanya aktifitas hewan, maupun akibat proses taponomi (Christensen et al., 2014).

Goresan pada periosteum menangkap serta merefleksikan radiasi sinar ultraviolet. Hal tersebut menyebabkan lapisan periosteum yang rusak menjadi berpendar selama pengamatan berlangsung. Bagian tulang yang sensitif atau mudah merefleksikan sinar ultraviolet adalah bagian kortikal, di mana bagian tersebut banyak terkandung protein berupa kolagen di dalamnya. Kolagen yang terurai menjadi molekul, bersifat sangat sensitif terhadap paparan sinar elektromagnetik bergelombang pendek, seperti sinar ultraviolet.

Hal tersebut juga dapat dimanfaatkan oleh Antropolog Forensik yang sedang memeriksa TKP, ketika ingin mencari fragmen tulang. Pencarian tersebut dapat dilakukan dengan menggunakan laser dari sinar ultraviolet, di mana fragmen tulang yang mengandung kolagen akan berpendar dan berwarna biru terang dari objek lainnya (Christensen et al., 2014).

Jadi penggunaan sinar ultraviolet sangat bermanfaat untuk mencari kerusakan periosteum hingga bagian kortikal terlihat. Pengamatan makroskopis dengan cahaya normal, tidak dapat memperlihatkan dengan jelas bentuk, ukuran, dan lokasi goresan atau kerusakan periosteum secara akurat.

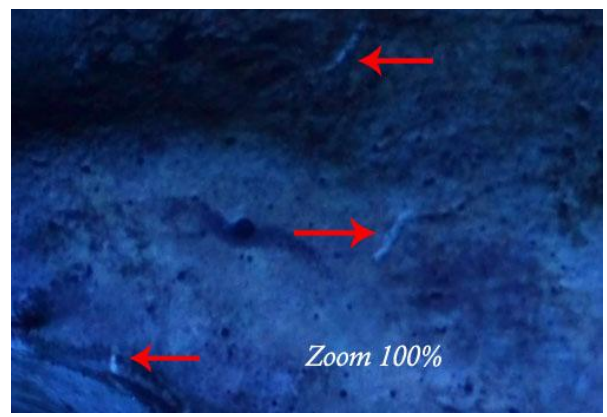




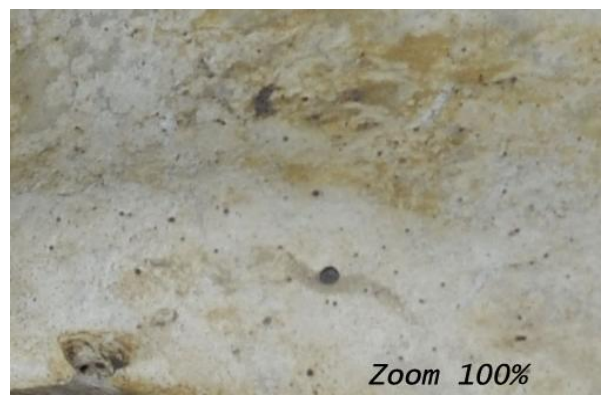

Gambar 17. Temuan abrasi pada periosteum terlihat lebih jelas dengan foto sinar UV (atas) dibandingkan dengan foto cahaya normal (bawah) Sumber: Dokumen pribadi

\subsection{Temuan kontak benda asing}

Pada gambar 18. dan 19., adanya kontak dengan kertas perekat pada cranium. Cranium diberi paparan sinar ultraviolet dan benda asing tersebut berpendar karena mengabsorbsi sinar ultraviolet yang datang. Pendaran tersebut terus bercahaya selama pengamatan berlangsung, oleh karena itu sifat pendaran dari benda asing ini adalah fosforesensi (Richards, 2010).

Temuan benda asing yang berpendar tersebut, diduga adalah sisa lem atau bahan perekat yang digunakan untuk merekonstruksi cranium. Lem dapat berpendar berwarna biru terang, disebabkan oleh bahan dasar dari lem yang mengandung polivinil asetat (PVA) bersifat sensitif terhadap sinar ultraviolet. Bahan perekat merupakan benda anorganik, secara umum mengandung luminescence merefleksikan atau mengabsorbsikan radiasi ultraviolet, dengan warna putih bercahaya hingga pendar kebiruan (Redsicker et al., 2001). Secara makroskopis dengan cahaya normal tidak terlihat sisa lem atau bahan perekat pada sutura coronalis, namun dengan paparan sinar ultraviolet sisa lem atau bahan perekat tersebut dapat terlihat atau teramati.

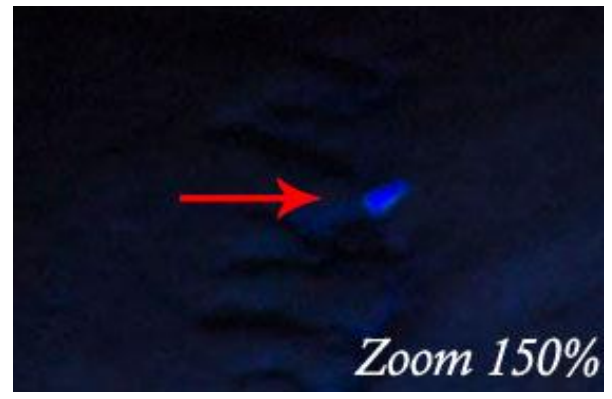

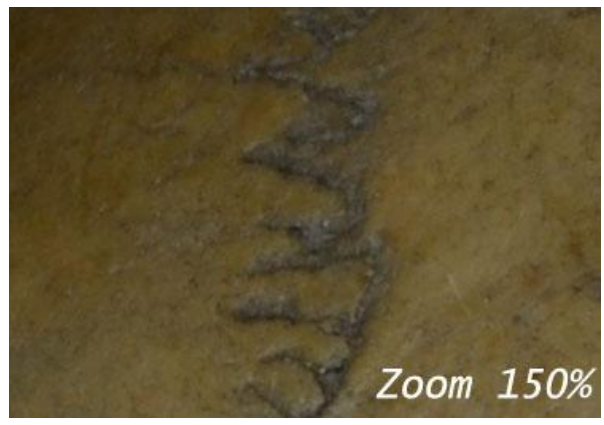

Gambar 18. Temuan kertas perekat terlihat lebih jelas dengan foto sinar UV (atas) dibandingkan dengan foto cahaya normal (bawah) Sumber: Dokumen pribadi
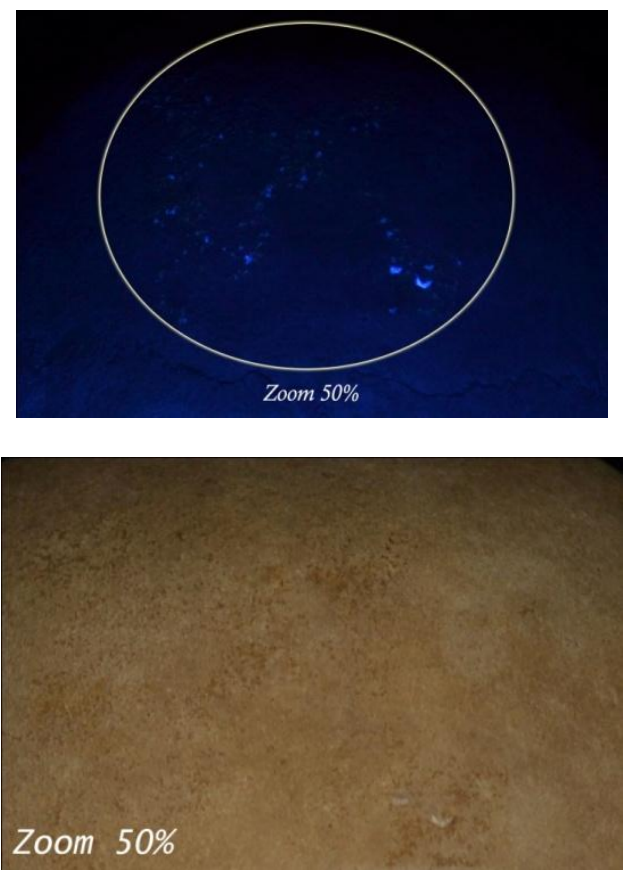

Gambar 19. Temuan kertas perekat terlihat lebih jelas dengan foto sinar UV (atas) dibandingkan dengan foto cahaya normal (bawah)

Sumber: Dokumen pribadi

Pada gambar 20., adanya kontak dengan butiran pasir pada cranium. Cranium diberi paparan sinar ultraviolet dan benda asing tersebut berpendar karena merefleksi radiasi ultraviolet yang datang. Titik-titik benda asing tersebut bersifat fluoresensi atau berpendar selama beberapa detik, dan berubah menjadi lebih gelap dari area di sekitarnya (Richards, 2010).

Temuan benda asing yang berpendar tersebut, diduga butiran pasir halus yang masuk ke dalam sutura lambdoid selama proses dekomposisi terjadi. Butiran pasir halus 
yang berbentuk partikel-partikel kecil, merefleksikan radiasi sinar ultraviolet sehingga mengeluarkan energi panas. Energi panas itulah yang berpendar selama beberapa detik dan berhasil ditangkap oleh lensa kamera. Butiran pasir tersebut berwarna kehijauan, dikarenakan mata manusia paling mudah menangkap warna hijau dalam gelombang spektrum yang terlihat (Marin \& Buszka, 2013). Secara makroskopis butiran pasir halus tersebut tidak dapat diamati dengan cahaya normal, namun dengan bantuan sinar ultraviolet partikel pasir tersebut dapat teramati atau terlihat dengan baik.
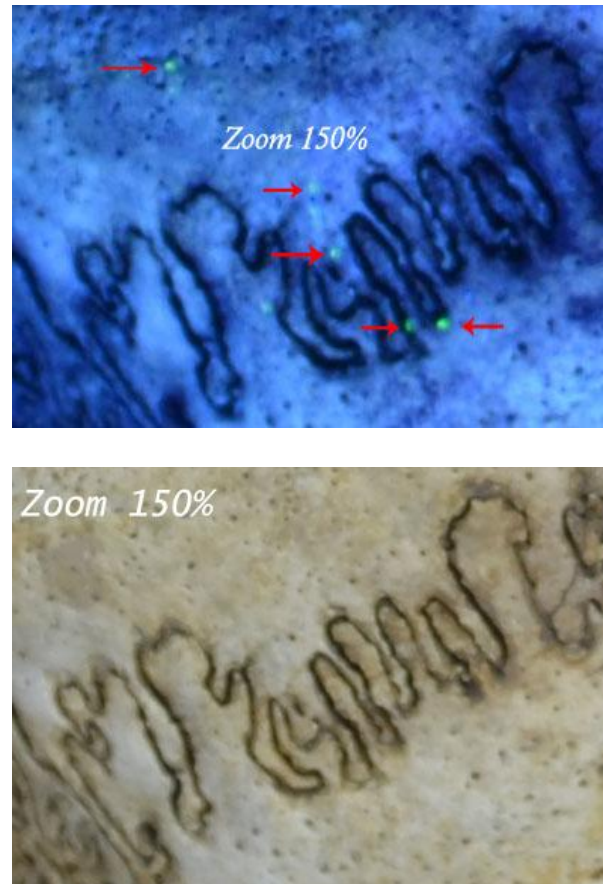

Gambar 20. Temuan pasir halus terlihat lebih jelas dengan foto sinar UV (atas) dibandingkan dengan foto cahaya normal (bawah) Sumber: Dokumen pribadi

Pada gambar 21. dan 22., adanya kontak dengan serat benang. Cranium diberi paparan sinar ultraviolet dan benda asing tersebut terlihat berpendar sesaat sebelum menghilang, atau berubah menjadi lebih gelap dari area di sekitarnya. Sifat pendaran cahaya yang sifatnya hanya sementara ini disebut dengan fluoresensi.

Fluoresensi terlihat akibat adanya radiasi ultraviolet yang ditangkap oleh benda asing tersebut, dan terrefleksi kemudian terlihat melalui lensa kamera (Marin \& Buszka, 2013). Temuan benda asing tersebut diduga adalah serat benang yang tidak diketahui asal muasalnya. Serat benang yang tertempel di area palatum diduga berasal dari kassa kontainer tempat penyimpanan, dapat juga berasal dari serat benang pakaian, dan berasal dari kain tempat display. Serat benang tersebut hanya dapat dilihat menggunakan sinar ultraviolet, karena dengan cahaya normal serat benang tersebut sama sekali tidak terlihat atau teramati.
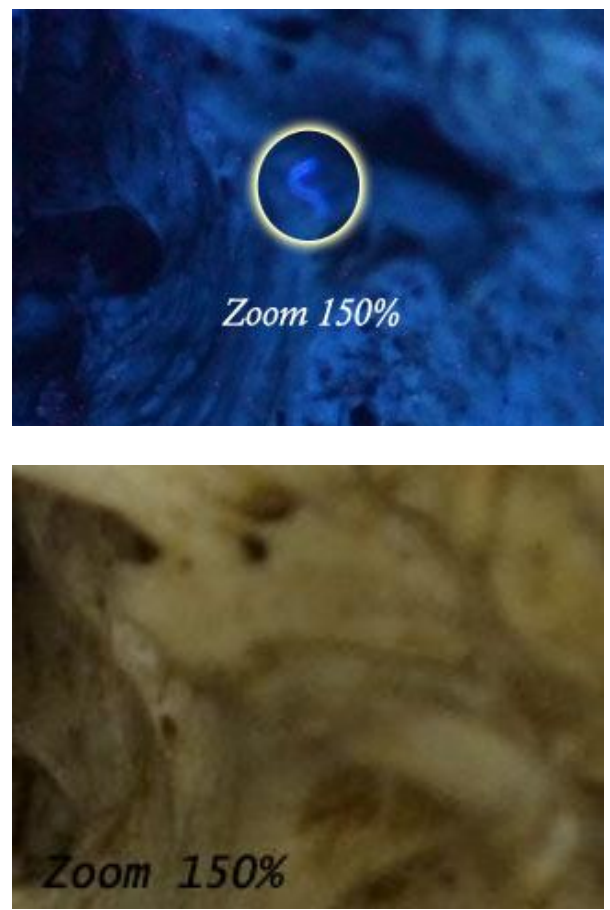

Gambar 21. Temuan serat benang terlihat lebih jelas dengan foto sinar UV (atas) dibandingkan dengan foto cahaya normal (bawah)

Sumber: Dokumen pribadi

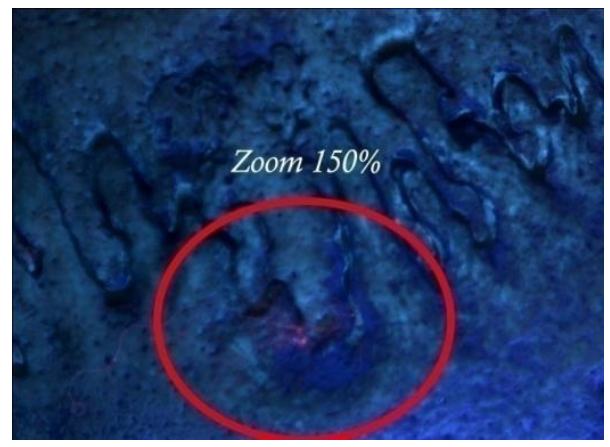




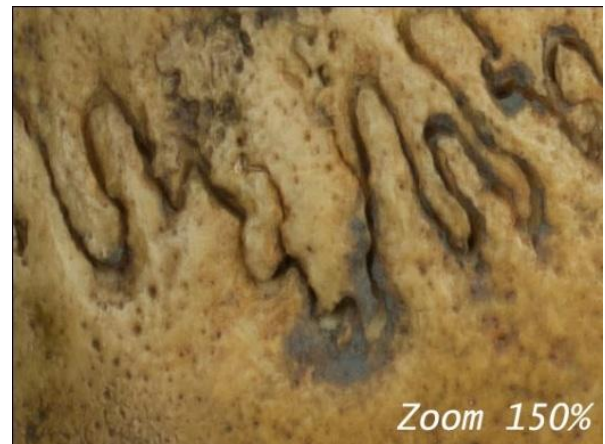

Gambar 22. Temuan serat benang terlihat lebih jelas dengan foto sinar UV (atas) dibandingkan dengan foto cahaya normal (bawah) Sumber: Dokumen pribadi

\section{SIMPULAN}

Penggunaan teknik ALS dengan pemaparan sinar inframerah dan ultraviolet pada cranium manusia, untuk mendeteksi adanya tanda-tanda kelainan cranium dapat dilakukan dengan baik. Tanda-tanda kelainan yang dapat terdeteksi tersebut antara lain adalah adanya abnormalitas pada cranium dan gigi, perbedaan struktur dan warna pada permukaan cranium, adanya modifikasi tulang, serta adanya kontak cranium dengan benda asing.

Pemaparan sinar inframerah pada cranium manusia, dapat bermanfaat untuk mendeteksi adanya tanda-tanda kelainan. Beberapa jenis kelainan yang dapat teramati pada cranium, adalah: (1) memperjelas adanya porotic; (2) menunjukkan penipisan periosteum; (3) memperjelas karies gigi; (4) memperjelas pengamatan sutura; (5) memperjelas adanya trauma; dan (6) menunjukkan perbedaan warna karena taponomi..

Pemaparan sinar ultraviolet pada cranium manusia, dapat bermanfaat untuk mendeteksi adanya tanda-tanda kelainan. Beberapa jenis kelainan yang dapat teramati pada cranium, adalah: (1) memperjelas adanya porotic; (2) memperjelas struktur permukaan gigi; (3) memperjelas calculus gigi; (4) memperjelas atrisi gigi; (5) memperjelas karies gigi; (6) menunjukkan adanya abrasi periosteum; (7) menunjukkan adanya aktifitas hewan; dan (8) menunjukkan kontak dengan kertas perekat, butiran pasir, dan serat benang.

\section{DAFTAR PUSTAKA}

Admin. (2013, November 17). Tips Fotografi Membuat Efek Foto Infrared dengan Photoshop. Dipetik Juli 30, 2015, dari

http://tipsfotografi.net/tips-

fotografi-membuat-efek-foto-

infrared-dengan-photoshop.html

Broux, S. T., McCaul, K. K., \& Shimamoto, S. (2007). Infrared Photography. Retrieved July 22, 2015, from http://www.crime scene-

investigator.net/Infrared_Photography_res earch_paper.pdf

Chhem, R. K., \& Brothwell, D. R. (2008). PaleoRadiology: Imaging Mummies and Fossils. New York: Springer.

Christensen, A. M., Passalacqua, N. V., \& Bartelink, E. J. (2014). Forensic Anthropology: Current Methods and Practice. Oxford: Elsevier Inc.

Council, N. R. (2001). Physics in a New Era: An Overview. Washington D.C.: National Academy Press.

Giancoli, D. C. (2005). Physics: Principles with Applications (Sixth Edit). New Jersey: Pearson Education, Inc. http://doi.org/10.1007/s13398-0140173-7.2

Huculak, M. A., \& Rogers, T. L. (2009). Reconstructing the Sequence of Events Surrounding Body Disposition Based on Color Staining of Bone. Journal of Forensic Sciences, 54(5), 979-984. http://doi.org/10.1111/j.15564029.2009.01086.x

Katzenberg, M. A., \& Saunders, S. R. (2008). Biological Anthropology of the Human Skeleton (Second Edi). New Jersey: John Wiley \& Sons, Inc.

Klingle, C., \& Reiter, K. (2008). Ultraviolet and Infrared Injury Photography. Evidence Technology Magazine.

Marin, N., \& Buszka, J. (2013). Alternate Light Source Imaging: Forensic Photography Techniques. (L. S. Miller, Ed.). Oxford: Elsevier Inc. Retrieved from https://www.dawsonera.com/readonline/9 781455775484 
Jurnal Biosains Pascasarjana Vol. 17 (2015) pp

(C) (2015) Program Pascasarjana Universitas Airlangga, Indonesia

Ortner, D. J. (2003). Identification of Pathological Conditions in Human Skeletal Remains (Second). Amsterdam: Academic Press.

Oxlee, G. (2000). Digital Imaging Enchancement. In J. Siegel, G. Knupfer, \& P. Saukko, Encyclopedia of Forensic Sciences, Volume 1-3 (pp. 12641269). Bureau: Academic Press.

Pokines, J. T., \& Symes, S. A. (2014). Manual of Forensic Taphonomy. Change. London: CRC Press LLC. http://doi.org/10.1201/9781439821923

Redsicker, D. R., James, S. H., Laws Jr., A. C., \& Redsicker, A. D. (2001). The Practical Methodology of Forensic Photography (Second Edi). New York: CRC Press LLC.

Richards, A. (2010). Reflected Ultraviolet Imaging for Forensics Applications. California.

Walker, P. L., Bathurst, R. R., Richman, R., Gjerdrum, T., \& Andrushko, V. A. (2009). The Causes of Porotic Hyperostosis and Cribra Orbitalia: A Reappraisal of the Iron-Deficiency-Anemia Hypothesis. American Journal of Physical Anthropology, 139(2), 109-125. http://doi.org/10.1002/ajpa.21031 